\title{
HERBACEOUS VEGETATION COMMUNITIES AROUND LAKE MANYARA, TANZANIA: RESPONSE TO ENVIRONMENTAL GRADIENTS
}

\author{
Gideon A. Mseja, Beatrice B. Furael, Gastor J. Lyakurwa, Emanuel H. Martin \\ College of African Wildlife Management, Tanzania \\ e-mail: galfred@mwekawildlife.ac.tz,bbenjamin@mwekawildlife.ac.tz, \\ glyakurwa@mwekawildlife.ac.tz,emartin@mwekawildlife.ac.tz
}

Received: 24.07.2019. Revised: 02.09.2020. Accepted: 08.09.2020.

\begin{abstract}
Healthy populations of wildlife require quality forage sufficiently available in both space and time. The herbaceous vegetation around rift valley lakes in Tanzania varies along productivity, disturbance and stress gradients. We have analysed herbaceous vegetation communities and ascertained the nature of their association with environmental variables around Lake Manyara in Kwakuchinja Wildlife Corridor. The transect method was used for sampling vegetation data. Environmental variables including soil $\mathrm{pH}$, available soil phosphorus, distance from the lakeshore, bare soils, soil water, soil salinity and soil total nitrogen were used as possible explanatory variables. Ordination was used to assemble the herbaceous plant communities and relate with the determined environmental variables. The Shannon-Wiener Index was employed to determine species diversity in each plant community. The results revealed three distinct grassland communities named after the dominant and subdominant species: Sporobolus spicatus, Sporobolus ioclados - S. spicatus and Cynodon dactylon. The Monte Carlo Permutation test revealed that soil $\mathrm{pH}$, available soil phosphorus, distance from the lakeshore and bare soil significantly correlated with herbaceous plant community assemblages. The indices of plant species richness and diversity reflected the influence of soil saturation gradients on plant communities. This study contributes to understanding spatial patterns of herbaceous plant communities around alkaline-saline lakes of the Gregory rift valley in East Africa. It also reveals an association between plant community structures with varying edaphic gradients. We conclude that our study forms the basis for monitoring herbaceous plant community change based on determined environmental variables in the corridors of wildlife conservation areas.
\end{abstract}

Key words: CANOCO, eigen-value, Kwakuchinja Wildlife Corridor, Monte-Carlo, simulation

\section{Introduction}

Wildlife management and pastoralism are prime economic activities in semi-arid grasslands around eastern rift valley lakes in East Africa (Yanda \& Madulu, 2005; Homewood et al., 2012). Persistence of these grasslands as foraging areas for ungulates requires land use planning for livestock rearing and/or wild herbivores management. There is a need to analyse the herbaceous vegetation in these areas to be able to answer some important ecological questions. These questions are whether there are spatial variations in herbaceous species composition and the determinants of such variation. Gradient analysis is an important approach to spatially and temporally describe largescale and local variations in plant community composition. Such patterns of variation in vegetation have been attributed to variation in resource availability, such as soil nutrients, water and light (Connel \& Orias, 1964; Scholes \& Walker, 1993; Gaston, 2000; Golodets et al., 2013), disturbances such as herbivory and trampling (Augustine \& McNaughton, 1998; Wüest et al., 2018), stress such as extreme $\mathrm{pH}$ and salinity (Begon et al.,
2006; Li \& Pennings, 2019) and interactions between productivity factors and disturbances (Wilson \& Tilman, 2002; Aarrestad et al., 2010). The relationship between environmental variables and species diversity and richness can be explained by intermediate disturbance and productivity hypotheses (Grime, 1973; Huston, 1979; Cornwell \& Grubb, 2003). These hypotheses predict a unimodal pattern with stress and competitive exclusion reducing diversity at extreme environmental conditions. Maximum diversity and richness occur at intermediate levels of disturbance and productivity. Rangeland fire, grazing and browsing are examples of disturbance whereas soil nutrients represent productivity (Holdo et al., 2009). Thus, co-existence of herbaceous plant species is dependent on plant community productivity, levels of disturbance and stressors as they regulate the vigor of competitively dominant species (Cornwell \& Grubb, 2003).

Soil properties such as nutrients, water content, $\mathrm{pH}$ and salinity also determine the variation in plant species richness, diversity and plant community composition (Scholes \& Walker, 1993; 
Begon et al., 2006). Soil nitrogen and phosphorus are soil macronutrients, which play a major role in primary productivity. They are important nutrients and often the limiting factors for productivity in the tropical grasslands. Nutrients ' concentration also influences the impact of herbivory on plants, and plant responses to herbivory (Bryant et al., 1983). In the dry tropics, where evaporative loss of water is high, soil water content is an important factor in determining primary productivity (Milchunas \& Lauenroth, 1993). Soil water determines mineralisation rate and soil nutrient mobility, hence making nutrients available to plants (De Neve \& Hofman, 2002). Water also influences physical structure and plant community composition of the arid and semi-arid savanna (Scholes \& Walker, 1993).

Begon et al. (2006) explained extreme soil pH and salinity as environmental stressors, which influence plant species composition, richness and diversity. Extreme $\mathrm{pH}$ affects soil nutrients and mineral mobilisation reducing plant productivity and hence influencing plant community assemblage. High acidity can increase the concentration of $\mathrm{Mn}^{2+}, \mathrm{Fe}^{3+}$ and $\mathrm{Al}^{3+}$ to toxic levels; whereas high alkalinity fixes $\mathrm{Fe}^{3+}, \mathrm{PHO}^{3+}$ and $\mathrm{Mn}^{2+}$ in a relatively insoluble state, and hence unavailable to plants (Larcher, 2003). Extreme levels of salinity are expected in arid and semi-arid areas due to water loss from the soil through evaporation, which leads to an accumulation of crystalline salts on the soil surface. Flooding of banks of sodic lakes and shallow ground water tables may be other factors contributing to high soil salinity adjacent to such lakes. High soil salt concentration interferes with plant osmosis, resisting nutrients and water absorption from the substrate (Van Langevelde et al., 2003; Begon et al., 2006). It is nutritive costly to tolerate such harsh conditions and hence only adapted herbaceous plants tolerate and survive in the mentioned areas influencing diversity, richness, dominance and other plant community characteristics.

The aim of this study was to assess the variation of herbaceous vegetation in relation to gradients of environmental variables in grasslands adjacent to Lake Manyara in Kwakuchinja Wildlife Corridor (KWC). Specifically, we aimed to (i) assess variation in herbaceous plant species diversity, species richness and plant community composition, and (ii) determine the best environmental predictors of herbaceous species variation. We hypothesised that herbaceous plant richness and diversity would be (i) positively related to the dis- tance from the shore of Lake Manyara, soil total nitrogen, available soil phosphorus and soil water concentration, and (ii) negatively related to soil $\mathrm{pH}$, density of ungulate faeces, soil electric conductivity (EC) and bare soil. We also predicted that soil-related predictors would be more influential than herbivory-related predictors.

\section{Material and Methods}

\section{Study area}

KWC is located in Northern Tanzania within the Maasai steppe in East Africa. It is located between $3.593889^{\circ}-3.800556^{\circ} \mathrm{S}$ and $35.80583^{\circ}$ $35.99028^{\circ} \mathrm{E}$. It covers $240 \mathrm{~km}^{2}$ and shares a border with Manyara Ranch to the north, Mswakini village to the northeast, Tarangire National Park to the east, Burunge Wildlife Management Area to the southeast, Vilima Vitatu village to the southwest and Lake Manyara to the west. A large proportion of this area was gazetted to form Burunge Wildlife Management Area, a type of Protected Area where wildlife management is under the custodianship of villages. The area is located in an inland drainage basin with an altitude range of 960-1200 m a.s.1. Lake Manyara is a saline alkaline rift valley lake with solute concentration levels influenced by the seasonal weather variations. The area is bisected by the Great North Highway. The focal area for this study was on the eastern side of Lake Manyara (Fig. 1).

KWC is located in the semi-arid climatic zone with mean annual rainfall of $600 \mathrm{~mm}$. The annual mean monthly temperature is $27^{\circ} \mathrm{C}$ with rainfall from November to mid-May and a long dry season from June to October (Pratt \& Gwynne, 1977). The area is characterised by plain soils with light colour, in association with black, poorly drained clay soils.

KWC connects Lake Manyara National Park and Tarangire National Park, forming part of the Tarangire - Manyara ecosystem. The high $\mathrm{pH}$ level of Lake Manyara's water is caused by alkaline volcanic bed rocks commonly produced by many volcanoes in East Africa (Yanda \& Madulu, 2005). Since human settlement and agriculture are prohibited close to Lake Manyara and inside Burunge Wildlife Management Area, common wildlife such as Phacochoerus africanus masaicus Lönnberg, 1908, Connochaetes taurinus Burchell, 1823, Aepyceros melampus Lichtenstein, 1812, and Equus quagga Gray, 1824, as well as livestock such as cattle, goats and sheep, use the area for grazing and drinking. 


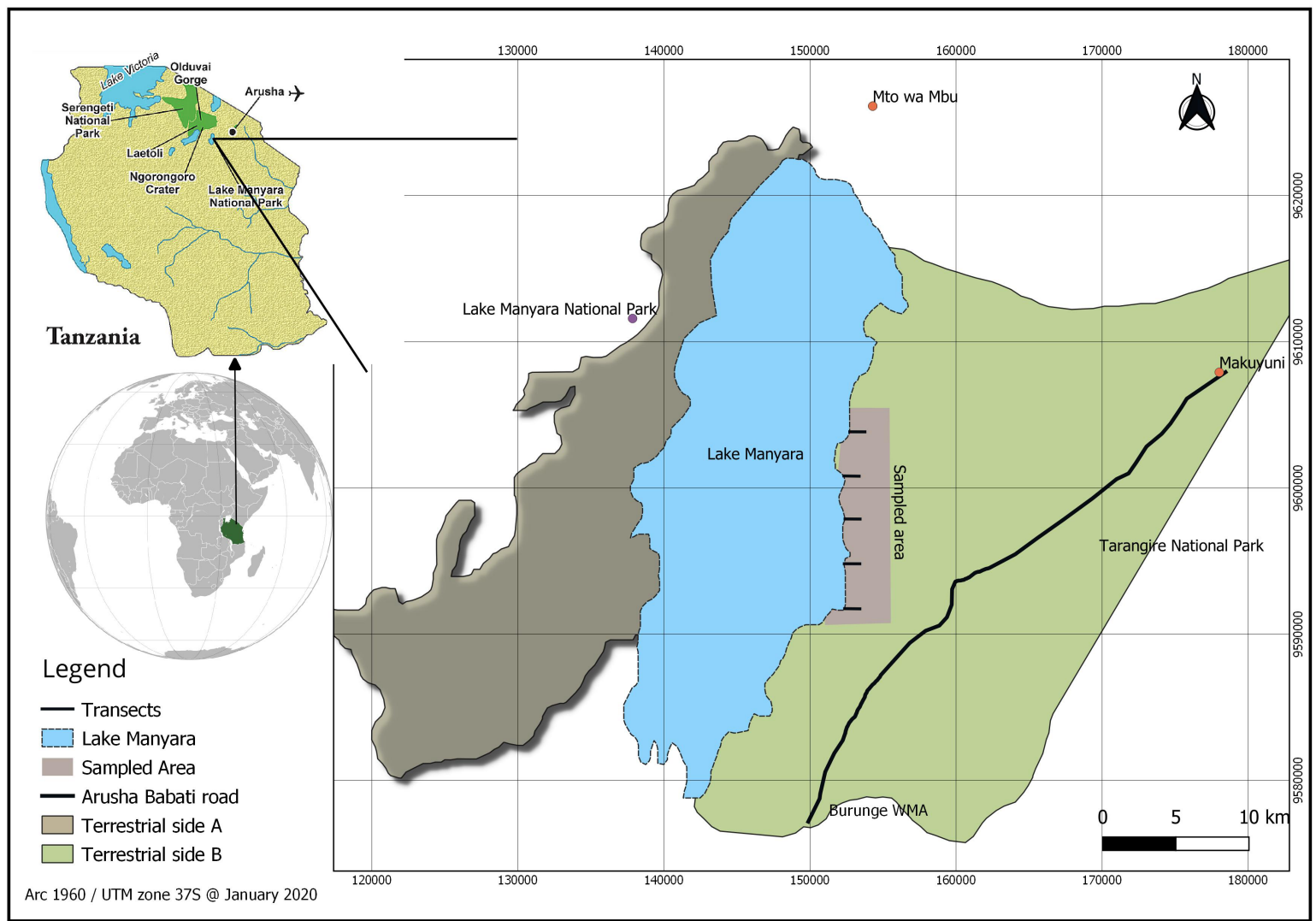

Fig. 1. Map of Africa (bottom left inset) showing the location of Tanzania (top left inset) and Lake Manyara (enlarged map). The study area was along the eastern side of Lake Manyara within the Kwakuchinja Wildlife Corridor where five transects (in the shaded strip) were laid.

\section{Data collection}

Vegetation data collection

We established five line transects running from west to east, perpendicular to the shoreline of Lake Manyara. The length of each transect was $950 \mathrm{~m}$, along which we made twenty sampling plots of $5 \times 5 \mathrm{~m}$ each. These sampling plots were $50 \mathrm{~m}$ from each other and we collected vegetation data from four randomly selected $1 \times 1 \mathrm{~m}$ quadrats within each plot. The distance between transects was $3 \mathrm{~km}$. In each $1 \times 1 \mathrm{~m}$ quadrat, we identified the herbaceous plants to species level and counted the total number of herbaceous plant species (Ghazanfar, 2006; Oudtshoorn, 2012; The Plant List, 2013; POWO, 2020), determined their abundance by counting individual shoots, and visually estimated the percentage of bare soil. In case of prostrate plants, we counted tillers to determine the abundance. To control the variation and avoid pseudo-replication we used the average scores from the four quadrats in each plot for further analysis. We determined the distances between sampling plots using a tape measure and distance between transects using hand held Global Positioning System device. We used a $5 \times 5 \mathrm{~m}$ grid made of polythene ropes to subdivide sampling plots into $1 \mathrm{~m}^{2}$ quadrats.

\section{Density of ungulate faeces}

We estimated the density of ungulate faeces within the $5 \times 5 \mathrm{~m}$ sampling plots by counting the number of pellet groups or dung pats. This work involved counting faeces during a setting of $25 \mathrm{~m}^{2}$ plots, clearing the plots of faeces on the same day and a revisit ten days later to count pellet groups and dung heaps. Thus, the density referred to here is the number of fecal pellet groups or dung pats deposited during a period of ten days in a $25 \mathrm{~m}^{2}$ plot.

\section{Soil sampling and chemical analysis}

For capturing data on soil $\mathrm{pH}$, soil total nitrogen, available phosphorus, soil water concentration and soil electric conductivity, we made one $10 \mathrm{~cm}$ deep and $7.6 \mathrm{~cm}$ wide soil core using an auger, in each of the four quadrats used to collect vegetation data. We thoroughly mixed soil samples from the four quadrats to make a single composite sample for each sampling plot. We weighed soil samples using an electronic balance in the field. Samples were air dried, appropriately labeled and stored in plastic sampling bags. Sample labels included transect number, sample plot number and GPS waypoints to ensure appropriate identification of samples during analysis. We sent all soil samples 
for analysis to the Agricultural Research Institute (ARI) Mlingano in Tanga, Tanzania. At ARI, all soil samples were sieved using a $2 \mathrm{~mm}$ sieve before chemical analyses. Soil $\mathrm{pH}$, both in distilled water and in $\mathrm{KCl}$, was analysed using a $\mathrm{pH}$ meter. However, we used only $\mathrm{pH}$ in $\mathrm{KCl}$ in the statistical analyses. To calculate soil moisture concentration, the difference between the fresh weight of the soil, and weight after $12 \mathrm{~h}$ oven drying of samples at $105^{\circ} \mathrm{C}$, was determined. Assessment of soil samples for available soil phosphorus ( $\mathrm{mg} / \mathrm{kg}$ ) was conducted colourimetrically with auto-analyser by extraction using sodium bicarbonate since all soil $\mathrm{pH}$ in water ranged from neutral to alkaline (Olsen et al., 1954). The total soil nitrogen was determined using the macro-Kjeldahl technique. Electric conductivity was determined using 1:2.5 soil: water suspension ratio (Bremner \& Mulvaney, 1982; Jones, 2018).

\section{Data analysis}

Species abundance in four $1 \times 1 \mathrm{~m}$ quadrats from each sampling plot were averaged and only one value, the mean abundance per $1 \mathrm{~m}^{2}$, was used per plot. All environmental variables originated from the $5 \times 5 \mathrm{~m}$ sampling plots. Since in this study, one of the interests was the impact of ungulates in general on herbaceous vegetation, we did not separate the density of faeces to individual ungulate species during analysis.

\section{Ordination of plant species data}

In order to identify plant communities, we performed multivariate analyses using CANOCO version 4.56 (ter Braak \& Šmilauer, 2002). Ordination summarises complex multivariate data by producing diagrams, which show clusters of samples. It can also associate species data with environmental variables (Gauch, 1982; McGarigal et al., 2013). We used an indirect analysis that showed the total variation of species data to identify sample clusters while overlaying predictors to explain their relations with species data (Jongman et al., 1995).

Before actual analysis, we conducted a model selection after establishment of the nature of species response to environmental variables. We determined the length of gradient, which was higher than the threshold value of 4 implying a unimodal model in the subsequent analysis (Lepš \& Šmilauer, 2003). We assessed outliers and realised that one sample had only one species (Sporobolus sanguineus Rendle) which occurred in very few other samples. Therefore, we down weighed the sample to remove the influence of outlying sam- ple. Furthermore, we log transformed the data $(\log +1)$ to control for a large variation of abundance values (0.25-245.50) and corrected for zeros in the data frame. We did not detect the horseshoe effect during diagnosis. We maintained all aforementioned data transformations throughout the analyses. We used Canonical Correspondence Analysis (CCA) to create an ordination graph for plant community clusters. To improve the clarity of graphs we used different colours and symbols on samples representing different clusters in the final ordination graph. We used only species data and environmental variables, not including covariables. Only significant environmental variables were used on the CanoDraw.

\section{Determination of significant environmental predictors of plant communities}

We performed CCA to statistically test the relationship between species data and environmental variables (Lepš \& Šmilauer, 2003). To test for the importance of environmental variables, we used manual forward selection with simulations using Monte Carlo Permutation tests. Statistical testing was done using this simulated data to make it free from any statistical assumption of response distribution. We performed 499 unrestricted permutation tests, which is a default setting in CCA. This analysis resulted into marginal values, which are Lambda $(\lambda)$, i.e., the amount of variation which is explained by individual predictors, and significance tests $(\mathrm{p}$ and $F$ values). Further tests involved determining the influence of each environmental variable when other variables are included in the model (conditional values given). All statistically significant predictors were included in the model and the total amount of variation explained was determined.

\section{Description of plant communities}

Herbaceous plant communities were described based on untransformed field data. We rearranged the species file as per plant community indicated by Canonical Correspondence Analysis, calculated species richness within plant communities, the total species abundance and diversity. Species richness in the plant community refers to the total number of species in a cluster of samples, while species diversity was a result of the Shannon-Wiener Index.

\section{Results}

This study used a total of 100 samples, 30 plant species and eight environmental variables. Out of 100 samples used, only 94 were active 
samples and six samples had no plant species. The analysis used a unimodal response of herbaceous plants to environmental variables in KWC. The collected and analysed environmental variables explained a very high proportion of variation in the species data, as shown by the sum of all canonical eigen-values of 0.82 .

\section{Herbaceous plant communities}

Three distinct clusters of samples representing three herbaceous plant communities in the study area were revealed. The first and second axes had eigen-values of 0.59 and 0.40 , and species-environmental correlation of 0.71 and 0.44 , respectively. The plant communities were named after dominant species, subdominant species, if any, and vegetation form. We defined dominant species as the most abundant species in the plant community and subdominant species were other species contributing more than $40 \%$ of the plant community's total abundance. The plant communities identified were Sporobolus spicatus grassland, Sporobolus ioclados - S. spicatus grassland and Cynodon dactylon grassland (Fig. 2).

\section{Plant communities description}

The three identified plant communities were characterised by differences in species dominance, abundance, diversity, richness and species uniqueness (Table 1). These plant communities were thoroughly described using various plant community characteristics as indicated below.

\section{Sporobolus spicatus grassland}

This plant community was characterised by Sporobolus spicatus (Vahl) Kunth as a dominant species, appearing in all samples. The only unique species in this plant community was Portulaca oleracea L., an annual succulent plant in the family Portulacaceae. Sporobolus spicatus is a clonal grass in the family Poaceae, possessing short tillers and a spike inflorescence. There was no subdominant species in this plant community. Other species with high frequency were Cyperus alatus subsp. albus (Nees) Lye, Cyperus rotundus L., Sporobolus ioclados (Nees ex Trin.) Nees. This plant community was negatively correlated with the distance from Lake Manyara shore, bare soil and available soil phosphorus. It was positively related to $\mathrm{pH}$ (Fig. 2). Sporobolus spicatus grassland contained a lower species richness and lower diversity than Sporobolus ioclados - S. spicatus grassland and Cynodon dactylon grassland (Table 1).

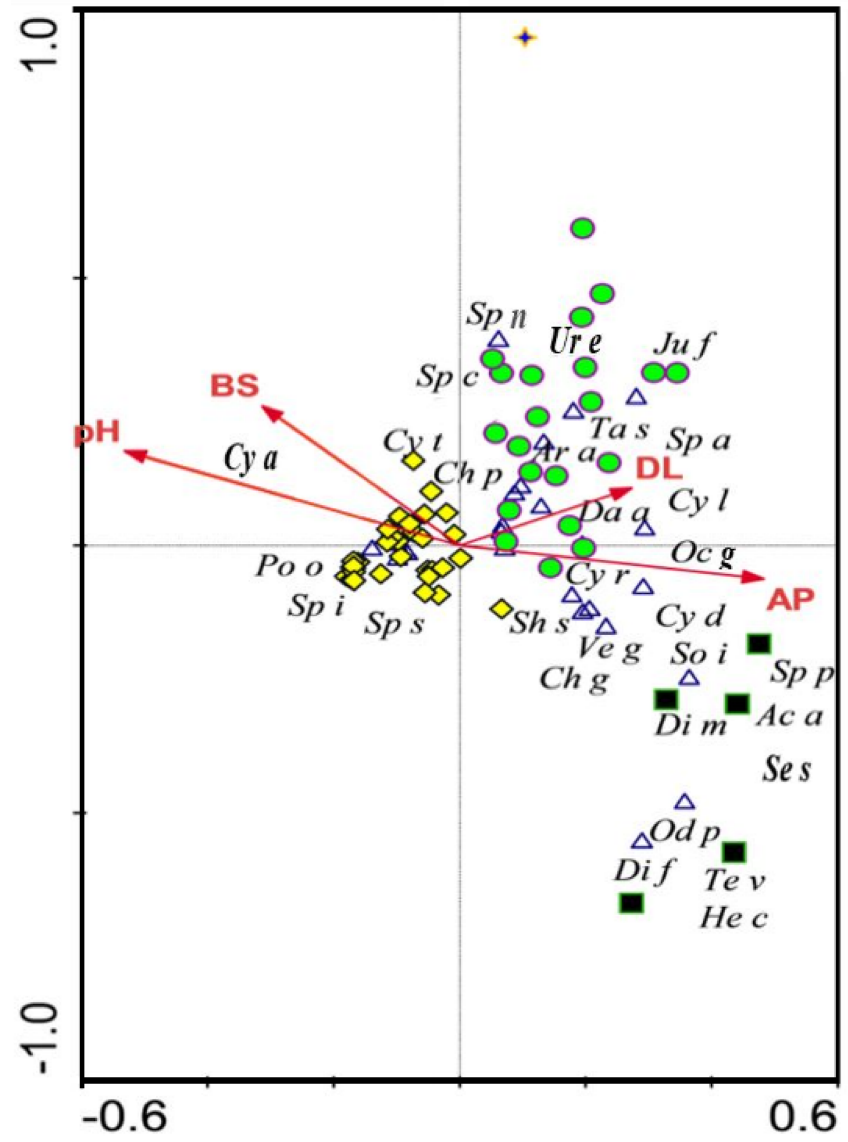

Fig. 2. Canonical Correspondence Analysis triplot diagram axis 1 (horizontal) and 2 (vertical) with significant environmental variables in the Kwakuchinja Wildlife Corridor. Coloured symbols correspond to sample clusters identified. Yellow diamonds are Sporobolus spicatus grassland, green circles are Sporobolus ioclados - S. spicatus grassland, and black squares are Cynodon dactylon grassland. Triangles represent species points. The blue star is a down-weighed outlier sample. Environmental variables are presented using red arrows where $\mathrm{BS}$ - Bare soil, DL - distance from Lake Manyara shore, $\mathrm{pH}$ - soil pH, and AP - available soil phosphorus. Acronyms of scientific names of plants are indicated in Appendix.

\section{Sporobolus ioclados - S. spicatus grassland}

This is a plant community with Sporobolus ioclados as a dominant and Sporobolus spicatus as a subdominant species. Sporobolus ioclados is a tufted Poaceae, rarely a stoloniferous plant, flourishing well in alkaline, saline and arid environments. Justicia flava (Forssk.) Vahl and Urochloa eminii (Mez) Davidse were unique species in this plant community. Other frequently encountered species in this plant community were Cyperus rotundus, Cyperus alatus, Chloris gayana Kunth, Dactyloctenium aegyptium L. (Wild), Chloris pycnothrix Trin, Vernonia galamensis (Cass.) Less., Sporobolus africanus (Poir.) Robyns \& Tournay, and Cynodon dactylon (L.) Pers. The plant community was positively correlated with the distance from Lake Manyara shore and with available phosphorus (Fig. 2). This herbaceous community had the highest species diversity and intermediate species richness (Table 1). 
Table 1. Description of herbaceous plant communities in Kwakuchinja Wildlife Corridor

\begin{tabular}{|c|c|c|c|}
\hline Parameter & Sporobolus spicatus grassland & Sporobolus ioclados - S. spicatus grassland & Cynodon dactylon grassland \\
\hline Total samples & 66 & 22 & 5 \\
\hline Species richness & 16 & 21 & 24 \\
\hline Species diversity $\left(\mathrm{H}^{\prime}\right)$ & 0.56 & 1.99 & 1.91 \\
\hline \multirow{2}{*}{ Dominant species } & \multirow{2}{*}{ Sporobolus spicatus } & Sporobolous ioclados & \multirow{2}{*}{ Cynodon dactylon } \\
\hline & & Sporobolous spicatus & \\
\hline \multirow{2}{*}{ Frequent species } & \multirow{2}{*}{ Portulaca oleracea } & \multirow{2}{*}{ Justicia flava } & Solanum incanum \\
\hline & & & Sesbania sericea \\
\hline \multirow{2}{*}{ Unique species } & \multirow{2}{*}{ Portulaca oleraceae } & Justicia flava & Solanum incanum \\
\hline & & Urochloa eminii & Sesbania sericea \\
\hline \multirow{10}{*}{ Other species } & Cyperus alatus & Cyperus rotundus & Cyperus rotundus \\
\hline & Cyperus rotundus & Cyperus alatus & Vernonia galamensis \\
\hline & Sporobolus ioclados & Chloris gayana & Digitaria milanjiana \\
\hline & & Dactyloctenium aegyptium & Sphaeranthus suaveolens \\
\hline & & Chloris pycnothrix & Ocimum gratismum \\
\hline & & Vernonia galamensis & Diplachne fusca \\
\hline & & Sporobolus africanus & Dactyloctenium aegyptium \\
\hline & & \multirow{3}{*}{ Cynodon dactylon } & Chloris gayana \\
\hline & & & Sporobolus ioclados \\
\hline & & & Odyssea paucinervis \\
\hline
\end{tabular}

\section{Cynodon dactylon grassland}

This plant community is dominated by Cynodon dactylon. The plant community occurs in patches amidst an expanse of the other two plant communities. Areas occupied by this plant community were along small and seasonal freshwater shallow pools or drains recharged by rainfall. This plant community had less bare soil than the other two grassland communities. Sesbania sericea (Wild.) Link. and Solanum incanum were unique species in this plant community. Other species were Cyperus rotundus, Vernonia galamensis, Digitaria milanjiana (Rendle) Stapf, Sphaeranthus suaveolens DC., Ocimum gratissmum Willd, Diplachne fusca (L.) P. Beauv. ex Roem. \& Schult., Dactyloctenium aegyptium (L.) Wild., Chloris gayana, Sporobolus ioclados, and Odyssea paucinervis (Nees) Staph. The plant community was positively related to available phosphorus and the distance from Lake Manyara shore and negatively related to $\mathrm{pH}$ and percentage bare soil (Fig. 2). More forbs were found in Cynodon dactylon grassland than in the other two plant communities. The species richness and diversity were higher in Cynodon dactylon grassland than in Sporobolus spicatus grassland (Table 1).

\section{Association of environmental predictors to plant communities}

Marginal values from forward selection using CCA and the Monte Carlo Permutation test indicated that six environmental variables were significantly correlated with variation in the species data (Table 2). The variables included were soil $\mathrm{pH}$, available soil phosphorus, bare soil, soil water concentration, electric conductivity and the distance from the lake shore $(p=0.002$ for all). Conditional values obtained during model se- lection reduced the number of significant predictors to four, i.e. soil $\mathrm{pH}$, available soil phosphorus, bare soil and the distance from the lake shore, explaining 54.4\% of all variation (Table 2). Thus, soil moisture concentration, electric conductivity, density of ungulate faeces and soil total nitrogen were not significant predictors and therefore not included in the ordination graph.

\section{Discussion}

This study demonstrated that herbaceous vegetation in grasslands around the shore of Lake Manyara can be grouped into three distinct plant communities dominated by different plant species. The three plant communities are related to the examined significant environmental variables. In line with our prediction, species diversity and richness were positively related to the distance from the lake shore and available soil phosphorus. This was signified by the fact that Sporobolus spicatus grassland, which occurred close to the lake shore, had lower available soil phosphorus. Similarly, this plant community had lower species richness and diversity than Sporobolus ioclados $-S$. spicatus and Cynodon dactylon grasslands communities. Plant communities with high species diversity and richness had lower soil $\mathrm{pH}$ and percentage of the cover of bare soil (Table 1; Fig. 2) as per our prediction. Except for the distance from the lake shore, the remaining three significant predictors were related to soil characteristics making soil properties more important predictors for herbaceous vegetation than herbivore-related predictors as hypothesised (Table 2). Contrary to our expectation, the percentage of soil water, electric conductivity, density of ungulate faeces and soil total nitrogen were not significantly related to the herbaceous vegetation (Table 2). 
Table 2. Canonical Correspondence Analysis statistical test results for environmental variables in Kwakuchinja Wildlife Area

\begin{tabular}{|l|l|c|c|c|c|c|}
\hline \multirow{2}{*}{\multicolumn{1}{c|}{ Environmental variables }} & \multicolumn{3}{c|}{ Marginal values } & \multicolumn{3}{c|}{ Conditional values } \\
\cline { 2 - 8 } & Lambda $(\lambda)$ & p value & F value & Lambda $(\lambda)$ & $p$ value & F value \\
\hline Soil pH in $\mathrm{KCl}$ & 0.25 & $\mathbf{0 . 0 0 2}$ & 5.47 & 0.25 & $\mathbf{0 . 0 0 2}$ & 5.65 \\
\hline Available soil phosphorus & 0.19 & $\mathbf{0 . 0 0 2}$ & 4.2 & 0.11 & $\mathbf{0 . 0 0 2}$ & 2.51 \\
\hline Bare soil & 0.16 & $\mathbf{0 . 0 0 2}$ & 3.53 & 0.1 & $\mathbf{0 . 0 0 2}$ & 2.38 \\
\hline Soil water concentration & 0.16 & $\mathbf{0 . 0 0 2}$ & 3.53 & 0.07 & 0.072 & 1.6 \\
\hline Electric conductivity & 0.13 & $\mathbf{0 . 0 0 2}$ & 2.89 & 0.06 & 0.092 & 1.48 \\
\hline Distance from lake shore & 0.12 & $\mathbf{0 . 0 0 2}$ & 2.69 & 0.09 & $\mathbf{0 . 0 1 2}$ & 1.99 \\
\hline Total nitrogen & 0.05 & 0.318 & 1.04 & 0.04 & 0.336 & 0.95 \\
\hline Density of ungulate faeces & 0.03 & 0.696 & 0.68 & 0.04 & 0.486 & 0.92 \\
\hline
\end{tabular}

Note: Significant $\mathrm{p}$ values at $\alpha=0.05$ are in bold; Lambda $(\lambda)$ and F-values shown.

Sporobolus ioclados - S. spicatus grassland and Cynodon dactylon grassland communities had virtually similar species diversity, i.e. 1.99 and 1.91 respectively. These two plant communities represented a relatively higher diversity than the Sporobolus spicatus community. The former two plant communities occurred in areas of similar soil characteristics, further away from the lake. This implies that extreme soil chemical conditions close to the lake shore negatively affect plant growth, reducing both abundance and species evenness of the Sporobolus spicatus community. Low mineral nutrients availability affects plant biomass production, ultimately reducing plant species richness (Ghazanfar, 2006; Luna et al., 2016). The findings are related to studies which suggested that some semi-arid herbaceous plant communities suffer from such a condition, leading to slow growing, long-lived and small-sized plants like Sporobolus spicatus (Golodets et al., 2013). Herbaceous plant communities with their characteristic species indicate underlying environmental conditions. For instance, $S$. spicatus herbaceous plant communities dominated close to Lake Manyara. This finding is supported by a study conducted in Lake Bogoria National Reserve in Kenya (Onkware, 2000). Sporobolus spicatus, dominating in the two plant communities, is a clonal and short grass capable of tolerating an alkaline environment. Comparatively, the difficulty for un-adapted species to colonise the hypoxic and nutrients-poor soil conditions contributes to a lower species diversity in this plant community (Luna et al., 2016).

Findings by Scholes \& Walker (1993), Milchunas \& Lauenroth (1993), Craine et al. (2008), Aarrestad et al. (2010) showed that in the tropics, soil properties can influence vege- tation stronger than herbivore-related variables. This may explain the relationships between plant communities, soil $\mathrm{pH}$, electric conductivity and available soil phosphorus levels in this study. Although the available soil phosphorus was low close to the lake shore as a result of a high $\mathrm{pH}$, generally high levels of phosphorus in other areas in KWC may be explained in two ways. Firstly, KWC lies on the Manyara volcanic paleo lake bed, with subsequent lacustrine sedimentation forming a series of phosphorites and bioturbated silty layers (Mutakyahwa, 2002; Bachofer et al., 2014). These ancient processes may have made KWC relatively rich in phosphorus (Mubyana et al., 2003; Yanda \& Madulu, 2005). Repeated grazing of Equus quagga and Connochaetes taurinus can further enhance phosphorus concentration in plant biomass (Harrison \& Bardgett, 2008).

An extremely high soil $\mathrm{pH}$ is an important stressor in grasslands around Lake Manyara. Most soil samples close to the lakeshore were alkaline with a decline in $\mathrm{pH}$ further away from the lake shore. Samples with a high percentage of bare soil also had high $\mathrm{pH}$ readings, probably due to the deposition of solutes on the soil surface following evaporation. Importantly, the high $\mathrm{pH}$ value interferes with nutrients uptake in the soil and ultimately affects the plant community structure (Larcher, 2003; Begon et al., 2006; Golodets et al., 2013; Li \& Pennings, 2019). A high soil $\mathrm{pH}$ may also be a function of bare soil since there was a prevalence of high $\mathrm{pH}$ and salinity in soil samples collected from the sampling plots with a high percentage of bare soil (Begon et al., 2006).

As one would expect in areas with a long evolutionary history of grazing, indices of ungulate use of the study area as explained by density 
of ungulate faeces had low explanatory power on plant species composition. This may be due to the fact that in these habitats short grasses compete only for soil resources, with occupation of above ground space maximised horizontally. Sporobolus spicatus and Cynodon dactylon are clonal grass species with a network of stolons and rhizomes connected over a large area. These species form a network of ramets sharing and reallocating resources to overcome damage caused by grazing and trampling (Wilsey, 2002). These results are in line with the findings by Milchunas \& Lauenroth (1993) and Wüest et al. (2018) who also reported little influence of grazers on plant community composition. Species which are not tolerant to grazing, such as many dicot herbs, may be eliminated with an increased herbivory pressure influencing plant community assemblage in the area (Milchunas et al., 1988; Makhabu et al., 2002).

\section{Conclusions}

We have seen that herbaceous vegetation in KWC riparian grassland in Northern Tanzania forms three distinct plant communities. These plant communities vary in species composition, dominance and uniqueness, species richness and diversity. Supporting a unimodal response of herbaceous plant species to environmental variables, findings of this study conform to most of our predictions. The fact that four environmental variables correlated with variations in plant communities, signifies a careful choice of predictors for the study. However, the number of herbaceous plant species identified in this area is lower than in tropical semi-arid savanna areas, a phenomenon which could be explained by the prevalence of alkaline soils that may limit the number of species tolerating those conditions. Our study forms the basis for monitoring herbaceous vegetation changes in these important wildlife habitats.

\section{Acknowledgements}

We express our gratitude to the College of African Wildlife Management, (CAWM) Mweka, for providing research grants. We thank Tanzania Wildlife Research Institute (TAWIRI), for providing a research permit, the CAWM's Kwakuchinja rangers, field assistants and drivers who helped us during data collection. We also extend our sincere thanks to Dr. Grainne Mc.Cabe, Dr. Trevor Jones and Dr. Andy Bowkett for English proofing. We are also greatly indebted by two anonymous reviewers for excellent directives and shaping up of this paper.

\section{References}

Aarrestad P.A., Masunga G.S., Hytteborn H., Pitlagano M.L., Marokane W., Skarpe C. 2010. Influence of soil, tree cover and large herbivores on field layer vegetation along a savanna landscape gradient in Northern Botswana. Journal of Arid Environments 75(3): 290 297. DOI: 10.1016/j.jaridenv.2010.10.009

Augustine D.J., McNaughton S.J. 1998. Ungulate Effects on the Functional Species Composition of Plant Communities: Herbivore Selectivity and Plant Tolerance. Journal of Wildlife Management 62(4): 1165-1183. DOI: $10.2307 / 3801981$

Bachofer F., Quénéhervé G., Märker M. 2014. The delineation of paleo-shorelines in the Lake Manyara basin using TerraSAR-X data. Remote Sensing 6(3): 2195 2212. DOI: $10.3390 /$ rs6032195

Begon M., Townsend C.R., Harper J.L. 2006. Ecology: From Individuals to Ecosystems. $4^{\text {th }}$ ed. Blackwell Publishing. 738 p.

Bremner J.M., Mulvaney C.S. 1982. Nitrogen total. In: A.L. Page, R.H. Miller, D.R. Keeney (Eds.): Methods of soil analysis. Madison: American Society of Agronomy and Soil Science Society of America. P. 595-624.

Bryant J.P., Chapin F.S., Klein D.R. 1983. Carbon/nutrient balance of boreal plants in relation to vertebrate herbivory. Oikos 40(3): 357-368. DOI: 10.2307/3544308

Connel J.H., Orias E. 1964. The Ecological Regulation of Species Diversity. The American Naturalist 98(903): 399-414.

Cornwell W.K., Grubb P.J. 2003. Regional and local patterns in plant species richness with respect to resource availability. Oikos 100(3): 417-428. DOI: 10.1034/j.16000706.2003.11697.x

Craine J.M., Morrow C., Stock W.D. 2008. Nutrient concentration ratios and co-limitation in South African grasslands. New Phytologist 179(3): 829-836. DOI: 10.1111/j.1469-8137.2008.02513.x

De Neve S., Hofman G. 2002. Quantifying soil water effects on nitrogen mineralization from soil organic matter and from fresh crop residues. Biology and Fertility of Soils 35(5): 379-386. DOI: 10.1007/s00374-002-0483-3

Gaston K.J. 2000. Global patterns in biodiversity. Nature 405: 220-227. DOI: 10.1038/35012228

Gauch H.G. 1982. Multivariate analysis in community ecology. Portland: Cambridge University Press. P. 109-172.

Ghazanfar S.A. 2006. Saline and alkaline vegetation of NE Africa and the Arabian Peninsula: An overview. In Biosaline Agriculture and Salinity Tolerance in Plants. Basel: Birkhäuser. P. 101-108.

Golodets C., Sternberg M., Kigel J., Boeken B., Henkin Z., Seligman N.G., Ungar E.U. 2013. From desert to Mediterranean rangelands: will increasing drought and inter-annual rainfall variability affect herbaceous annual primary productivity? Climatic Change 119(34): 785-798. DOI: $10.1007 / \mathrm{s} 10584-013-0758-8$ 
Grime J.P. 1973. Control of species density on herbaceous vegetation. Journal of Environmental Management 1: 151-167.

Harrison A.K., Bardgett R.D. 2008. Impacts of grazing and browsing by large mammals on soils and soil biological properties. In: I.J. Gordon, H.H.T. Prins (Eds.): The Ecology of Browsing and Grazing. Heidelberg: Springer. P. 201-202.

Holdo R.M., Holt R.D., Fryxell J.M. 2009. Grazers, browsers, and fire influence the extent and spatial pattern of tree cover in the Serengeti. Ecological Applications 19(1): 95-109. DOI: 10.1890/07-1954.1

Homewood K.M., Trench P.C., Brockington D. 2012. Pastoralist livelihoods and wildlife revenues in East Africa: a case for coexistence? Pastoralism: Research, Policy and Practice 2(1): 19. DOI: 10.1186/2041-7136-2-19

Huston M. 1979. A general hypothesis of species diversity. The American Naturalist 113(1): 81-101. DOI: 10.1086/283366

Jones J. 2018. Soil analysis handbook of reference methods. CRC Press. 264 p.

Jongman R.H.G., ter Braak C.J.F., Van Tongeren O.F.R. 1995. Data analysis in community and landscape ecology. Portland: Cambridge University Press. 111 p.

Larcher W. 2003. Physiological Plant Ecology. $4^{\text {th }}$ ed. Berlin: Springer Verlag. 514 p.

Lepš J., Šmilauer P. 2003. Multivariate Analysis of Ecological Data Using CANOCO. Cambridge: Cambridge University Press. 269 p. DOI: 10.1017/ CBO9780511615146

Li F., Pennings S.C. 2019. Response and Recovery of Low-Salinity Marsh Plant Communities to Presses and Pulses of Elevated Salinity. Estuaries and Coasts 42(3): 708-718. DOI: 10.1007/s12237-018-00490-1

Makhabu S.W., Marotsi B., Perkins J. 2002. Vegetation gradients around artificial water points in the Central Kalahari Game Reserve of Botswana. African Journal of Ecology 40(2): 103-109. DOI: 10.1046/j.13652028.2002.00306.x

McGarigal K., Cushman S.A., Stanford S. 2013. Multivariate Statistics for Wildlife and Ecology Research. Springer Science and Business Media. 282 p.

Milchunas D.G., Lauenroth W.K. 1993. Quantitative effects of grazing on vegetation and soils over a global range of environments. Ecological Monographs 63(4): 327 366. DOI: $10.2307 / 2937150$

Milchunas D.G., Sala O.E., Lauenroth W.K. 1988. A generalized model of the effects of grazing by large herbivores on grassland community structure. The American Naturalist 132(1): 87-106. DOI: DOI: 10.1086/284839

Mubyana T., Krah M., Totolo O., Bonyongo M. 2003. Influence of seasonal flooding on soil total nitrogen, organic phosphorus and microbial populations in the Okavango Delta, Botswana. Journal of Arid Environments 54(2): 359-369. DOI: 10.1006/jare.2002.1095
Mutakyahwa M.K.D. 2002. Mineralogy and chemistry of bentonite (?) deposits at Minjingu, Lake Manyara, North Tanzania. Journal of African Earth Sciences 34(3-4): 213-221. DOI: 10.1016/S08995362(02)00020-9

Olsen S.R., Cole C.V., Watanabe F.S., Dean L.A. 1954. Estimation of available phosphorus in soils by extraction with Sodium bicarbonate. New York: U.S Department of Agriculture, Circular 939, 19 p.

Onkware A.O. 2000. Effect of soil salinity on plant distribution and production at Loburu delta, Lake Bogoria National Reserve, Kenya. Austral Ecology 25(2): 140-149. DOI: 10.1046/j.1442-9993.2000.01020.x

Oudtshoorn F.V. 2012. Guide to Grasses of Southern Africa. Pretoria: Briza Publications. 288 p.

POWO. 2020. Plants of the World Online. Facilitated by the Royal Botanic Gardens. Available from http://www. plantsoftheworldonline.org

Pratt D.J., Gwynne M.D. (Eds.). 1977. Rangeland Management and Ecology in East Africa. London; Sydney; Auckland; Toronto: Hodder \& Stoughton. 310 p.

Scholes R.J., Walker B.H. 1993. An African savanna: synthesis of the Nylsvley study. Cambridge: Cambridge University Press. 236 p.

terBraak C.J.F., Šmilauer P. 2002. CANOCO Reference Manual and CanoDraw for Windows User's Guide: Software for Canonical Community Ordination (Version 4.5). New York: Microcomputer Power, Ithaca. $500 \mathrm{p}$.

The Plant List. 2013. The Plant List, version 1.1. Available from http://www.theplantlist.org

Van Langevelde F., Van De Vijver C.A., Kumar L., Van De Koppel J., De Ridder N., Van Andel J., Skidmore A.K., Hearne J.W., Stroosnijder L., Bond W.J., Prins H.H. 2003. Effects of fire and herbivory on the stability of savanna ecosystems. Ecology 84(2): 337-350. DOI: 10.1890/0012-9658(2003)084[0337:EOFAHO]2.0.CO;2

Wilsey B. 2002. Clonal plants in a spatially heterogeneous environment: effects of integration on Serengeti grassland response to defoliation and urine-hits from grazing mammals. Plant Ecology 159(1): 1522. DOI: $10.1023 / \mathrm{A}: 1015556816307$

Wilson S.D., Tilman D. 2002. Quadratic variation in old-field species richness along gradients of disturbance and nitrogen. Ecology 83(2): 492-504. DOI: $10.2307 / 2680030$

Wüest R.O., Münkemüller T., Lavergne S., Pollock L.J., Thuiller W. 2018. Integrating correlation between traits improves spatial predictions of plant functional composition. Oikos 127(3): 472-481. DOI: 10.1111/oik.04420

Yanda P.Z., Madulu N.F. 2005. Water resource management and biodiversity conservation in the Eastern Rift Valley Lakes, Northern Tanzania. Physics and Chemistry of the Earth 30(11): 717-725. DOI: 10.1016/j.pce.2005.08.013 
Appendix. Herbaceous plants in Kwakuchinja Wildlife Corridor, acronyms and families.

\begin{tabular}{|c|c|c|c|}
\hline No & Plant species name & Acronym & Family \\
\hline 1 & Achyranthes aspera L. & Ac a & Amaranthaceae \\
\hline 2 & Aristida adscensionis L. & Ar a & Poaceae \\
\hline 3 & Chloris gayana Kunth & $\mathrm{Chg}$ & Poaceae \\
\hline 4 & Chloris pycnothrix Trin. & $\mathrm{Ch} p$ & Poaceae \\
\hline 5 & Cynodon dactylon (L.) Pers. & Cy d & Poaceae \\
\hline 6 & Cyperus alatus subsp. albus (Nees) Lye & Cy a & Cyperaceae \\
\hline 7 & Cyperus laevigatus L. & Cy 1 & Cyperaceae \\
\hline 8 & Cyperus rotundus L. & Cy r & Cyperaceae \\
\hline 9 & Cyperus tenax Boeckeler & $\mathrm{Cyt}$ & Cyperaceae \\
\hline 10 & Dactyloctenium aegyptium (L.) Wild. & Da a & Poaceae \\
\hline 11 & Digitaria milanjiana (Rendle) Stapf & Di m & Poaceae \\
\hline 12 & Diplachne fusca (L.) P.Beauv. ex Roem. \& Schult. & Dif & Poaceae \\
\hline 13 & Heteropogon contortus (L.) P.Beauv. ex Roem. \& Schult. & $\mathrm{He} \mathrm{c}$ & Poaceae \\
\hline 14 & Justicia flava (Forssk.) Vahl & Ju f & Acanthaceae \\
\hline 15 & Ocimum gratissimum L. & Oc $g$ & Labiatae \\
\hline 16 & Odyssea paucinervis (Nees) Staph & Od p & Poaceae \\
\hline 17 & Portulaca oleracea L. & Po o & Portulacaceae \\
\hline 18 & Sesbania sericea (Willd.) Link & Se s & Leguminosae \\
\hline 19 & Solanum incanum L. & So i & Solanaceae \\
\hline 20 & Sphaeranthus suaveolens DC. & Sh s & Asteraceae \\
\hline 21 & Sporobolus africanus (Poir.) Robyns \& Tournay & Sp a & Poaceae \\
\hline 22 & Sporobolus consimilis Fresen. & Sp c & Poaceae \\
\hline 23 & Sporobolus ioclados (Nees ex Trin.) Nees & Sp i & Poaceae \\
\hline 24 & Sporobolus pyramidalis P.Beauv. & Sp p & Poaceae \\
\hline 25 & Sporobolus sanguineus Rendle & Sp n & Poaceae \\
\hline 26 & Sporobolus spicatus (Vahl) Kunth & Sp s & Poaceae \\
\hline 27 & Talinum spp. & Ta s & Talinaceae \\
\hline 28 & Tephrosia villosa (L.) Pers. & Te v & Leguminosae \\
\hline 29 & Urochloa eminii (Mez) Davidse & Ur e & Poaceae \\
\hline 30 & Vernonia galamensis (Cass.) Less. & Ve $g$ & Asteraceae \\
\hline
\end{tabular}

\title{
СООБЩЕСТВА ТРАВЯНИСТОЙ РАСТИТЕЛЬНОСТИ В ОКРЕСТНОСТЯХ ОЗЕРА МАНЯРА (ТАНЗАНИЯ): РЕАКЦИЯ НА ГРАДИЕНТЫ ОКРУЖАЮЩЕЙ СРЕДЫ
}

\author{
Г. А. Мсейа, Б. Б. Фураэль, Г. Дж. Лякурва, Э. Г. Мартин \\ Колледж управления дикой природой Африки, Танзания \\ e-mail: galfred@mwekawildlife.ac.tz,bbenjamin@mwekawildlife.ac.tz, \\ glyakurwa@mwekawildlife.ac.tz, emartin@mwekawildlife.ac.tz
}

Благополучные популяции диких животных нуждаются в качественных кормах, достаточно доступных как в пространстве, так и во времени. Травянистая растительность вокруг озер рифтовой долины в Танзании различается в зависимости от продуктивности, степени нарушения и градиентов стресса. Мы проанализировали сообщества травянистой растительности и выяснили характер их связи с переменными окружающей средой вокруг озера Маняра в Коридоре дикой природы Квакучинья. Для сбора данных о растительности использовался метод трансект. В качестве возможных объясняющих переменных были взяты экологические переменные, включая рН почвы, содержание доступного фосфора в почве, расстояние от берега озера, обнаженные почвы, содержание воды в почве, засоленность почвы и общее содержание азота в почве. Для построения сообществ травянистых растений и выявления связи с определенными переменными окружающей среды был использован метод ординации. Индекс Шеннона-Вивера был использован для определения видового разнообразия в каждом растительном сообществе. Результаты выявили три различных травянистых сообщества, названных по доминирующим и субдоминирующим видам: сообщество Sporobolus spicatus, сообщество Sporobolus ioclados - S. spicatus и сообщество Cynodon dactylon. Пермутационный тест по методу Монте-Карло выявил, что $\mathrm{pH}$ почвы, содержание доступного фосфора в почве, расстояние от берега озера и обнаженные почвы значительно коррелировали с сообществами травянистых растений. Показатели видового богатства и разнообразия растений отражали влияние градиентов насыщенности почвы на растительные сообщества. Это исследование способствует пониманию пространственной структуры сообществ травянистых растений вокруг щелочных засоленных озер рифтовой долины Грегори в Восточной Африке. Это также показывает связь между структурами растительного сообщества и различными эдафическими градиентами. Мы пришли к выводу, что данное исследование формирует основу для мониторинга изменений сообществ травянистых растений на основе определенных переменных окружающей среды в коридорах заповедников дикой природы.

Ключевые слова: CANOCO, Коридор дикой природы Квакучинья, метод Монте-Карло, симуляция, характеристическое число 